\title{
EFEKTIFITAS PENGGUNAAN DIAGRAM PUTAR DAN BUKU SAKU MKJP TERHADAP PENGETAHUAN AKSEPTOR
}

\author{
EFFECTIVENESS THE USE OF DIAGRAM AND MKJP POCKET BOOK ON \\ ACCEPTOR KNOWLEDGE \\ ${ }^{1 *}$ Ruwayda, ${ }^{2}$ Defirson \\ ${ }^{1 *, 2}$ Poltekkes Kemenkes Jambi \\ Kontak koresponden: ruwayda@poltekkesjambi.ac.id
}

\begin{abstract}
ABSTRAK
MKJP merupakan metode kontrasepsi jangka panjang yang sesuai dengan keadaan pandemi dimana mengurangi kontak secara rutin dengan petugas kesehatan. Akan tetapi, penggunaan KB MKJP yaitu IUD di bulan Februari 2020 sebanyak 36.155 akseptor turun menjadi 23.383 akseptor di bulan Maret 2020. Sedangkan untuk alat kontrasepsi Implan juga menurun dari 81.062 akseptor di bulan Februari menjadi 51.536 akseptor di bulan Maret. Proporsi MKJP yang rendah tidak hanya secara nasional tetapi juga terjadi di Provinsi Jambi. Tujuan penelitian ini adalah untuk melihat efektiftas penggunaan diagram putar dan buku saku MKJP terhadap pengetahuan akseptor. Metode penelitian quasi eksperimen dengan rancangan Two Group Pretest Posttest Penelitian dilaksanakan Januari-September 2021 Populasi semua akseptor KB yang berkunjung ke Puskesmas Putri Ayu tahun 2021. Data diperoleh melalui kuesioner pre test dan post test. Hasil penelitian ini menunjukkan sebelum penggunaan diagram putar dan buku saku MKJP sebagian besar responden memiliki pengetahuan yang kurang dan sesudah penggunaan memiliki pengetahuan yang baik. Tidak ada perbedaan efektivitas penggunaan diagram putar dan buku saku MKJP terhadap Pengetahuan Akseptor karena kedua intervensi memiliki nilai p $0,000<0,05$. Disarankan melakukan promosi kesehatan menggunakan diagram putar dan buku saku MKJP untuk meningkatkan keikutsertaan Pasangan Usia Subur.
\end{abstract}

Kata Kunci: Diagram Putar ; Buku Saku ; MKJP

\section{ABSTRACT}

MKJP is a long-term contraceptive method that is suitable for pandemic conditions where it reduces routine contact with health workers. However, the use of the MKJP KB, namely the IUD in February 2020, decreased by 36,155 acceptors to 23,383 acceptors in March 2020. Meanwhile, implant contraceptives also decreased from 81,062 acceptors in February to 51,536 acceptors in March. The low proportion of MKJP is not only national but also occurs in Jambi Province. The purpose of this study was to see the effectiveness of using rotary charts and MKJP pocket books on the knowledge of acceptors. Quasi-experimental research method with Two Group Pretest Posttest design. The study was conducted from January to September 2021. The population was all family planning acceptors who visited Putri Ayu Health Center in 2021. Data were obtained through pre-test and post-test questionnaires. The results of this study indicate that before the use of the rotary chart and the MKJP pocket book, most of the respondents had poor knowledge and after the use they had good knowledge. There was no difference in the 
effectiveness of the use of rotary charts and MKJP pocket books on Acceptor Knowledge because both interventions had a $p$ value of $0.000<0.05$. It is recommended to carry out health promotion using a rotary chart and MKJP pocket book to increase the participation of couples of childbearing age.

\section{Keywords: Rotary Chart ; Pocket book ; Long-term contraceptive method}

\section{Pendahuluan}

Salah satu pemerintah upaya pemerintah melakukan program keluarga berencana adalah upaya mengatur kelahiran anak, jarak dan usia ideal melahirkan, mengatur kehamilan, melalui promosi, perlindungan, dan bantuan sesuai dengan hak reproduksi untuk mewujudkan keluarga yang berkualitas keluarga berencana merupakan massalah satu strategi untuk mengurangi kematian ibu khususnya ibu dengan kondisi 4T yaitu terlalu muda melahirkan (di bawah usia 20 tahun), terlalu sering melahirkan, terlalu dekat jarak melahirkan, dan terlalu tua melahirkan (di atas usia 35 tahun) (Sari et al., 2015). Pemerintah juga berupaya agar Ibu dan Bayinya dapat sehat dengan menerapkan continuity of care secara komprehensif (Podungge, 2020).

Kunjungan ulang peserta KB (akseptor lama) dan atau kunjungan peserta baru (akseptor baru), merupakan upaya mendapatkan pelayanan alat kontrasepsi yang bertujuan untuk merintangi kehamilan. Penggunaan alat kontrasepsi tidak saja untuk Pasangan Usia Subur (PUS) yang berencana menjarangkan kelahiran, tetapi juga untuk PUS yang akan menunda kehamilan dan atau bahkan mengakhiri kehamilan/ kesuburan (Dewiyanti, 2020; Wulandari et al., 2020). Kunjungan akseptor lama atau akseptor baru mengharuskan keluar rumah dan bertemu dengan tenaga kesehatan untuk mendapatkan pelayanan kontrasepsi (Nurrasyidah et al., 2017; Revinovita, 2020). Pasangan usia subur harus dapat menjaga dan memanfaatkan reproduksinya yaitu menekan angka kelahiran dengan metode keluarga berencana sehingga jumlah dan interval kehamilan dapat diperhitungkan untuk meningkatkan kualitas reproduksi dan kualitas generasi yang akan datang (Aqmal, 2020; Eka Nur Rahayu \& Fitriani Mediastuti, 2021). Metode Kontrasepsi Jangka Panjang (MKJP) IUD dan implan adalah metode kontrasepsi paling efektif yang tahan lama, efisien, nyaman dan biayanya relatif murah dibandingkan non-MKJP (Rodiani et al., 2019). Pada massa pandemi yang mengharuskan pembatasan kunjungan ke fasilitas kesehatan, MKJP merupakan metode kontrasepsi jangka panjang yang sesuai dengan keadaan pandemi dimana mengurangi kontak secara rutin dengan petugas kesehatan (Bernadus et al., 2013).

Berdasarkan hasil SDKI 2012 prevalensi KB aktif di Indonesia 58\% wanita berstatus kawin umur 15-49 tahun menggunakan metode modern dan 4\% menggunakan metode tradisional. Suntikan KB adalah metode kontrasepsi yang paling banyak digunakan, diikuti oleh pil, masing-masing sebesar 32\% dan 14\%. Kemudian Intra Uterine Device (IUD) sebesar 4\%, susuk KB/implan sebesar 3,3\%, secara medis yaitu Medis Operatif Wanita (MOW) sebesar $3,2 \%$, sedangkan untuk pria yaitu Medis Operatif Pria (MOP) dan penggunaan kondom masih sangat rendah yaitu sebesar 3\% (Aliyudin \& Budyanra, 2017). 
Data menunjukan terjadi penurunan peserta KB pada bulan Maret 2020 jika dibandingkan dengan bulan Februari 2020. Penggunaan IUD di bulan Februari 2020 sebanyak 36.155 turun menjadi 23.383 di bulan Maret 2020. Sedangkan untuk alat kontrasepsi Implan, total penggunaan menurun dari angka 81.062 di bulan Februari menjadi 51.536 di bulan Maret (Humas BKKBN, n.d.). Proporsi MKJP yang rendah juga terjadi di Provinsi Jambi. Proporsi peserta KB Aktif Jenis kontrasepsi Metode Kontrasepsi Jangka Panjang (MKJP) IUD untuk peserta KB Aktif sebesar 6,71\%, sedangkan peserta KB Baru sebesar 3,33\%, Implan untuk peserta KB aktif 15,26\% dan peserta KB baru 9,8\% (Kementerian Kesehatan Republik Indonesia, 2014)

Survei data awal yang di lakukan di Puskesmas Putri Ayu Kota Jambi yang memakai KB dari bulan Januari sampai Mei terdapat 510 Akseptor dan melakukan wawancara di dapatkan hasil 6 tidak mengetahui tentang Metode Kontrasepsi Jangka Panjang (MKJP) dan 4 tidak mengetahui Metode Kontrasepsi Jangka Panjang (MKJP).

\section{Metode}

Penelitian ini adalah penelitian quasi eksperimental dengan rancangan Two Group Pretest Posttest bertujuan untuk mengetahui Pengaruh Penggunaan Diagram Putar dan Buku Saku KB MKJP terhadap pengetahuan Akseptor di Puskesmas Putri Ayu Kota Jambi 2021. Instrumen Penelitan ini adalah kuesioner analisis univariat dan bivariat dengan pengujian data menggunakan uji statistik $t$-test dependen apabila data penelitian berdistribusi normal, jika data penelitian tidak berdistribusi normal menggunakan uji wilcoxon. Penelitian ini dilaksanakan pada bulan Januari-September 2021 Populasi dalam penelitian ini adalah semua akseptor KB yang berkunjung ke Puskesmas Putri Ayu dari bulan Januari-Agustus yang menggunakan KB. Untuk menentukan sample menggunakan teknik random sampling yang mana teknik ini merupakan penentuan sampel dengan pertimbangan tertentu yang dibuat oleh peneliti dengan cara menetapkan kriteria inklusi dan eksklusi. Penelitian ini dilakukan di Puskesmas Putri Ayu Kota Jambi tahun 2021.

\section{Hasil}

Tabel 1. Distribusi Pengetahuan Sebelum Penggunaan Diagram Putar MKJP

\begin{tabular}{clcc}
\multicolumn{4}{c}{ di Puskesmas Putri Ayu Kota Jambi } \\
\hline No. & Pengetahuan & Jumlah & $\%$ \\
\hline 1 & Baik & 0 & 0 \\
\hline 2 & Cukup & 8 & 26.7 \\
\hline 3 & Kurang & 22 & 73.3 \\
\hline & Total & 30 & 100
\end{tabular}

Berdasarkan hasil penelitian memperlihatkan pengetahuan sebelum penggunaan diagram putar MKJP di Puskesmas Putri Ayu Kota Jambi 2021 sebagian besar responden memiliki pengetahuan yang kurang.

Tabel 2. Distribusi Pengetahuan Sesudah Penggunaan Diagram Putar MKJP di Puskesmas Putri Ayu Kota Jambi 


\begin{tabular}{cccc}
\hline No. & Pengetahuan & Jumlah & $\%$ \\
\hline 1 & Baik & 24 & 80 \\
\hline 2 & Cukup & 6 & 20 \\
\hline 3 & Kurang & 0 & 0 \\
\hline & Total & 30 & 100 \\
\hline
\end{tabular}

Berdasarkan hasil penelitian memperlihatkan pengetahuan sesudah penggunaan diagram putar MKJP di Puskesmas Putri Ayu Kota Jambi 2021 diketahui bahwa sebagian besar responden memiliki pengetahuan yang baik.

Tabel 3.Distribusi Pengetahuan Sebelum Penggunaan Buku Saku MKJP di Puskesmas Putri Ayu Kota Jambi 2021

\begin{tabular}{cccc}
\hline No. & Pengetahuan & Jumlah & $\%$ \\
\hline 1 & Baik & 0 & 0 \\
\hline 2 & Cukup & 12 & 40 \\
\hline 3 & Kurang & 18 & 60 \\
\hline \multicolumn{2}{r}{ Total } & 30 & 100 \\
\hline
\end{tabular}

Berdasarkan hasil penelitian memperlihatkan pengetahuan responden sebelum penggunaan buku saku MKJP di Puskesmas Putri Ayu Kota Jambi 2021 sebagian besar memiliki pengetahuan yang kurang.

Tabel 4.Distribusi Pengetahuan Sesudah Penggunaan Buku Saku MKJP di Puskesmas Putri Ayu Kota Jambi

\begin{tabular}{cccc}
\hline No. & Pengetahuan & Jumlah & $\%$ \\
\hline 1 & Baik & 29 & 96.7 \\
\hline 2 & Cukup & 1 & 3.3 \\
\hline 3 & Kurang & 0 & 0 \\
\hline & Total & 30 & 100 \\
\hline
\end{tabular}

Berdasarkan hasil penelitian memperlihatkan pengetahuan sesudah penggunaan buku saku MKJP di Puskesmas Putri Ayu Kota Jambi 2021 diketahui bahwa sebagian besar responden memiliki pengetahuan yang baik.

Tabel 5.Efektiftas Penggunaan Diagram Putar dan Buku Saku MKJP terhadap Pengetahuan Akseptor di Puskesmas Putri Ayu Kota Jambi

\begin{tabular}{lcccc}
\hline Intevensi & Kelompok & Mean & Std. Deviation & P value \\
\hline Diagram & Pretest & 4,80 & 1,064 & 0,000 \\
putar MKJP & Posttest & 8,27 & 0,868 & \\
\hline Buku saku & Pretest & 5,33 & 0,922 & 0,000 \\
MKJP & Posttest & 8,83 & 0,834 & \\
\hline
\end{tabular}

Berdasarkan hasil penelitian dapat diketahui bahwa hasil uji wilcoxon menunjukkan bahwa tidak ada perbedaan efektivitas penggunaan diagram putar dan buku saku MKJP terhadap Pengetahuan Akseptor di Puskesmas Putri Ayu Kota Jambi

\section{Pembahasan}


Berdasarkan hasil penelitian memperlihatkan pengetahuan sebelum penggunaan diagram putar MKJP di Puskesmas Putri Ayu Kota Jambi 2021 sebagian besar responden memiliki pengetahuan yang kurang. Pengetahuan yang kurang dapat dilihat dari sebagian besar responden yang tidak tahu pada pernyataan tentang "keuntungan pemakaian IUD, kepanjangan kontrasepsi MKJP, kontrasepsi yang berbentuk huruf $\mathrm{T}$, kecil, berupa kerangka dari plastik, kerugian pemakaian kontrasepsi IUD dan keuntungan kontrasepsi implant masing”. Beberapa responden yang memiliki pengetahuan yang cukup dapat dilihat dari sebagian besar jawaban responden yang sebelum penggunaan diagram putar MKJP, sebagian besar responden tahu pada pernyataan tentang "indikasi pemakaian kontrasepsi IUD, kontrasepsi implan termasuk jenis kontrasepsi, efek samping kontrasepsi implan dan manfaat kontrasepsi tubektomi.

Pengetahuan adalah merupakan hasil dari tahu dan ini terjadi setelah orang melakukan penginderaan terhadap suatu objek tertentu. Penginderaan terjadi melalui pancaindera manusia yakni penglihatan, pendengaran, penciuman, rasa dan raba. Sebagian besar pengetahuan manusia diperoleh melalui mata dan telinga (Notoatmodjo, 2018).Hasil penelitian tentang peningkatan pengetahuan ibu tentang metode kontrasepsi jangka panjang sebagai upaya menekan risiko kehamilan menunjukkan bahwa pengetahuan ibu sebelum penyuluhan adalah 9 orang termasuk kategori pengetahuan baik, 6 orang pengetahuan cukup dan 1 orang pengetahuan kurang (Susanti et al., 2020).

Berdasarkan hasil penelitian ini, dapat disimpulkan bahwa sebelum penggunaan diagram putar, sebagian besar responden memiliki pengetahuan yang kurang. Pengetahuan yang kurang disebabkan karena kurangnya kesadaran responden, kurangnya sarana dan prasarana untuk memperoleh informasi serta kondisi ibu yang tidak memiliki waktu untuk mencari informasi karena mengurus anak di rumah. Harapan kepada petugas kesehatan untuk meningkatkan promosi kesehatan dengan menggunakan media yang mudah dipahami, dibaca dan mampu menambah pengetahuan seperti diagram putar MKJP.

Berdasarkan hasil penelitian memperlihatkan pengetahuan sesudah penggunaan diagram putar MKJP di Puskesmas Putri Ayu Kota Jambi diketahui bahwa sebagian besar responden memiliki pengetahuan yang baik. Pengetahuan responden yang baik dapat dilihat dari sebagian besar responden tahu pada pernyataan tentang kepanjangan kontrasepsi MKJP, manfaat kontrasepsi tubektomi, indikasi pemakaian Kontrasepsi IUD dan tujuan kontrasepsi tubektomi. Beberapa responden yang memiliki pengetahuan cukup dapat dilihat dari sebagian besar responden yang tidak tahu pada pernyataan tentang keuntungan kontrasepsi implan, keuntungan pemakaian IUD dan kontrasepsi Implan termasuk jenis kontrasepsi.

Diagram merupakan media yang menggambarkan struktur dari obyek tertentu secara garis besar, diagram menunjukkan hubungan yang ada antara komponennya atau sifat-sifat proses yang ada disana. Isi diagram pada umumnya berupa petunjuk untuk memahami komponen dan mekanisme kerja peralatan tertentu. Misalnya kalau kita membeli peralatan elektronik, biasanya disertai sebuah diagram mengenai komponen alat tersebut, fungsi, dan cara pengoperasian. Jika digunakan dalam pembelajaran, diagram bisa menyederhanakan sesuatu yang kompleks sehingga dapat membantu memperjelas penyajiannya. 
Berdasarkan hasil penelitian ini, dapat disimpulkan bahwa sesudah penggunaan diagram putar MKJP, terdapat perubahan dan peningkatan pengetahuan responden. Pengetahuan responden yang meningkat dikarenakan pemberian informasi melalui diagram putar yang menggunakan gambar dengan ikon yang menjelaskan dari masing-masing kontrasepsi MKJP dengan bahasa yang jelas dan mudah dimengerti sehingga mampu memberikan pemahaman kepada responden.

Berdasarkan hasil penelitian memperlihatkan pengetahuan responden sebelum penggunaan buku saku MKJP di Puskesmas Putri Ayu Kota Jambi 2021 sebagian besar memiliki pengetahuan yang kurang.

Pengetahuan responden yang kurang dapat dilihat dari sebagian besar responden yang tidak tahu pada pernyataan tentang kepanjangan kontrasepsi MKJP, kerugian pemakaian kontrasepsi IUD, kontrasepsi Implan termasuk jenis kontrasepsi dan efek samping Kontrasepsi Implan".Sedangkan pengetahuan responden yang cukup dapat dilihat dari sebagian besar responden tahu pada pernyataan tentang keuntungan kontrasepsi implan, kontrassepsi yang berbentuk huruf T, kecil, berupa kerangka dari plastik dan keuntungan pemakaian IUD.

Pengetahuan/kognitif merupakan domain yang sangat penting dalam membentuk tindakan seseorang.Sebelum orang mengadopsi perilaku baru di dalam diri orang tersebut terjadi proses yang berurutan yaitu menyadari dalam arti mengetahui terlebih dahulu terhadap stimulus, tertarik pada stimulus, menimbang baik dan tidaknya stimulus tersebut baginya, mencoba perilaku baru, dan telah berperilaku baru yang sesuai dengan pengetahuan, kesadaran dan sikapnya terhadap stimulus (Nursalam, 2015).

Hasil penelitian terbaru juga menunjukkan bahwa terdapat pengaruh komunikasi, informasi dan edukasi (KIE) terhadap tingkat pengetahuan pasangan usia subur (PUS) dalam pemakaian metode kontrasepsi jangka panjang menunjukkan bahwa rata-rata tingkat pengetahuan Pasangan Usia Subur dalam pemakaian metode kontrasepsi jangka panjang sebelum diberikan komunikasi, informasi dan edukasi (KIE) yaitu 59,09 dengan standar deviasi (SD) yaitu 12,58. Tingkat pengetahuan maximum responden 20 dan tingkat pengetahuan minimum 9 di kelurahan rimbo kaluang wilayah kerja puskesmas padang pasir kota Padang .

Berdasarkan hasil penelitian ini, dapat disimpulkan bahwa sebelum penggunaan buku saku MKJP, responden masih memiliki pengetahuan yang rendah. Hal ini dikarenakan kurangnya paparan informasi yang diterima oleh responden baik melalui inisiatif diri sendiri ataupun promosi kesehatan dari petugas kesehatan. Untuk itu, sebaiknya petugas kesehatan dapat meningkatkan perannya dengan memberikan promosi kesehatan yang menarik perhatian responden salah satunya seperti buku saku MKJP.

Berdasarkan hasil penelitian memperlihatkan pengetahuan sesudah penggunaan buku saku MKJP di Puskesmas Putri Ayu Kota Jambi 2021 diketahui bahwa sebagian besar responden memiliki pengetahuan yang baik. Pengetahuan responden yang baik dapat dilihat dari sebagian besar responden tahu pada pernyataan tentang keuntungan kontrasepsi implan, kontrassepsi yang berbentuk huruf $\mathrm{T}$, kecil, berupa kerangka dari plastic, keuntungan pemakaian IUD dan manfaat kontrasepsi tubektomi. Sedangkan pengetahuan yang cukup dapat dilihat dari sebagian besar 
responden yang tidak tahu pada pernyataan tentang kerugian pemakaian kontrasepsi IUD, indikasi pemakaian Kontrasepsi IUD dan kontrasepsi Implan termasuk jenis kontrasepsi”.

Buku saku dipergunakan dalam penyampaian sosialisasi atau menampilkan suatu pokok bahasan atau materi khusus yang dipersembahkan untuk kalayak masyarakat. Seorang doctor bisa membuat buku saku sebagai media sosialisasi atau menyampaikan materi terkaiat ilmu kedokterannya kemudian bisa dibuat oleh suatu perusahan dalam memasarkan produk, dibuat oleh pihak berwajib sebagai alat untuk sosialisasi peraturan tertentu, dibuat oleh seorang pengajar untuk mempermudah penyampaian kepada warga belajar. Hasil penelitian yang menunjukkan bahwa terdapat pengaruh komunikasi, informasi dan edukasi (KIE) terhadap tingkat pengetahuan pasangan usia subur (PUS) dalam pemakaian metode kontrasepsi jangka panjang yang menunjukkan bahwa ratarata tingkat pengetahuan PUS dalam pemakaian metode kontrasepsi jangka panjang sesudah diberikan komunikasi, informasi dan edukasi (KIE) yaitu 81,27 dengan standar deviasi (SD) yaitu 7,94. Tingkat pengetahuan maksimum responden 24 dan tingkat pengetahuan minimum responden 16 di kelurahan rimbo kaluang wilayah kerja puskesmas padang pasir kota Padang (Fransisca \& Pebrina, 2019).

Berdasarkan hasil penelitian ini, dapat disimpulkan bahwa setelah diberikan literasi kesehatan menggunakan media video animasi, terdapat peningkatan antara pengetahuan responden sebelum dan sesudah. Pengetahuan responden yang meningkat dikarenakan adanya pemberian literasi kesehatan pada saat ibu berkunjung ke Posyandu yang sangat mudah diakses sehingga mempermudah ibu mencari informasi. Untuk itu, kepada pihak puskesmas dan kader posyandu dapat menjadikan literasi kesehatan sebagai salah satu media animasi yang digunakan untuk meningkatkan pengetahuan karena menarik dan mudah dipahami oleh ibu.

Hasil penelitian ini menunjukkan bahwa penggunaan diagram putar dan buku saku MKJP memiliki efektivitas yang sama terhadap pengetahuan akseptor. Hal ini juga dapat dilihat dari nilai rata-rata pengetahuan sebelum dan sesudah penggunaan diagram putar dan buku saku yang mengalami peningkatan secara bermakna. Tingkat pengetahuan ibu akseptor dipengaruhi oleh paparan informasi yang dapat diberikan dalam berbagai bentuk pendidikan kesehatan . Bentuk pemberian pendidikan kesehatan diantaranya adalah diagram dan buku saku. Diagram/skema merupakan suatu gambar sederhana yang menggunakan garis-garis dan simbol-simbol. Kelebihan diagram dapat menyajikan materi yang luas dan kompleks menjadi lebih padat dan sederhana.Sedangkan buku saku adalah jenis media cetak yang memiliki ukuran kecil dan ringan, dapat disimpan di dalam kantong baju dan simpel untuk di bawah serta dibaca kemanapun dan kapanpun. Cakupan dalam mengunakan buku saku lumayan luas. Buku saku merupakan media cetak yang berukuran kecil yang bisa disimpan dikantong baju serta praktis dibawa kemana saja (Mesra, 2018; Septianingrum et al., 2019).

Penelitian ini didukung oleh penelitian yang menunjukkan bahwa terdapat pengaruh komunikasi, informasi dan edukasi (KIE) terhadap tingkat pengetahuan pasangan usia subur (PUS) dalam pemakaian metode kontrasepsi jangka panjang yang dilihat berdasarkan hasil uji $\mathrm{t}$ dependen nilai $\rho=0,000$ (Fransisca \& Pebrina, 2019).

Berdasarkan hasil penelitian ini, dapat disimpulkan bahwa pemberian intervensi baik 
menggunakan diagram putar maupun buku saku MKJP memberikan dampak positif terhadap peningkatan pengetahuan. Hal ini dikarenakan kedua intervensi memiliki kelebihan yang sama2 memudahkan akseptor KB untuk memahami dan menerima informasi mengenai MKJP. Untuk itu, penggunaan diagram putar dan buku saku MKJP dapat dijadikan rekomendasi bagi petugas kesehatan sebagai salah satu upaya untuk meningkatkan pengetahuan akseptor KB tentang MKJP.

\section{Kesimpulan}

Hasil penelitian menunjukkan bahwa sebelum penggunaan diagram putar MKJP sebagian besar responden memiliki pengetahuan yang kurang dan sesudah penggunaan diagram putar MKJP sebagian besar responden memiliki pengetahuan yang baik. Hasil penelitian menunjukkan bahwa sebelum penggunaan buku saku MKJP sebagian besar responden memiliki pengetahuan yang kurang dan sesudah penggunaan buku saku MKJP sebagian besar responden memiliki pengetahuan yang baik. Tidak ada perbedaan efektivitas penggunaan diagram putar dan buku saku MKJP terhadap Pengetahuan Akseptor di Puskesmas Putri Ayu Kota Jambi.

\section{Referensi}

Aliyudin, F., \& Budyanra. (2017). Faktor-Faktor yang Memengaruhi Komplikasi Persalinan Wanita Usia Subur di Indonesia Menggunakan Data SDKI 2012 (Aplikasi Analisis Regresi Logistik Biner Multilevel). Jurnal Aplikasi Statistika \& Komputasi Statistik, 8.2.2016.

Aqmal, R. (2020). Pendidikan Keluarga Dan Partisipasi Masyarakat Pada Program Keluarga Berencana Di Masa Pandemi Covid-19 Desa Kerandin Kecamatan Lingga Timur Kabupaten Lingga. TANJAK: Journal of Education and Teaching, 1(2). https://doi.org/10.35961/tanjak.v1i2.159

Bernadus, J. D., Madianung, A., \& Masi, G. (2013). Faktor-Faktor Yang Berhubungan Dengan Pemilihan Alat Kontrasepsi Dalam Rahim (Akdr) Bagi Akseptor Kb Di Puskesmas Jailolo. E-NERS, 1(1). https://doi.org/10.35790/ens.v1i1.1760

Dewiyanti, N. (2020). Hubungan Umur Dan Jumlah Anak Terhadap Penggunaan Metode Kontrasepsi Di Puskesmas Bulak Banteng Surabaya. Medical Technology and Public Health Journal, 4(1). https://doi.org/10.33086/mtphj.v4i1.774

Eka Nur Rahayu, \& Fitriani Mediastuti. (2021). Penguatan Bidan Dalam Pelayanan Kesehatan Reproduksi Dan Keluarga Berencana Di Masa Pandemi Covid-19. J.Abdimas: Community Health, 2(2). https://doi.org/10.30590/jach.v2n2.337

Fransisca, D., \& Pebrina, M. (2019). Pengaruh KIE Terhadap Tingkat Pengetahuan Pasangan Usia Subur Dalam Pemakaian Alat Kontrasepsi Jangka Panjang. JIK- JURNAL ILMU KESEHATAN, 3(2). https://doi.org/10.33757/jik.v3i2.208

H, P. S., Hapsari, D., Dharmayanti, I., \& Kusumawardani, N. (2015). Faktor-Faktor Yang Berpengaruh Terhadap Risiko Kehamilan "4 Terlalu (4-T)" Pada Wanita Usia 10-59 Tahun (Analisis RISKESDAS 2010). Media Penelitian Dan Pengembangan Kesehatan, 24(3). https://doi.org/10.22435/mpk.v24i3.3649.143-152

Humas BKKBN. (n.d.). Dampak Pandemi Covid-19 Bagi Program KB di Indonesia. VOA Indonesia. https://www.voaindonesia.com/a/dampak-pandemi-covid-19-bagi-program-kbdi-indonesia/5411570.html

Kementerian Kesehatan Republik Indonesia. (2014). Sitasi dan Analisis Keluarga Berencana. 
Kementerian Kesehatan Republik Indonesia. https://pusdatin.kemkes.go.id/download.php?file=download/pusdatin/infodatin/infodatinkb.pdf

Mesra, E. (2018). Pendampingan Ibu Hamil Trimester Iii Tentang Pengetahuan Metode Kontrasepsi Jangka Panjang Di Tangerang. Jurnal Medikes (Media Informasi Kesehatan), 5(1). https://doi.org/10.36743/medikes.v5i1.50

Notoatmodjo Soekidjo. (2018). Metodologi Penelitian Kesehatan. In Rineka Cipta.

Nurrasyidah, N., Purwara, B. H., Herman, H., Husin, F., Djuwantono, T., Afriandi, I., \& Sukandar, H. (2017). Pengaruh Penerapan Booklet Kunjungan pada Akseptor KB Suntik 3 Bulan terhadap Pengetahuan, Sikap, dan Ketepatan Waktu Kunjungan Ulang. Jurnal Pendidikan Dan Pelayanan Kebidanan Indonesia, 3(1). https://doi.org/10.24198/ijemc.v3i1.50

Podungge, Y. (2020). Asuhan Kebidanan Komprehensif Comprehensive Midwifery Care. Jambura Health and Sport Journal, 2(2).

Revinovita, R. (2020). Hubungan Lama Penggunaan Intrauterine Device Dengan Kadar Hemoglobin Pada Akseptor Kb Iud Di Wilayah Kerja Puskesmas Bangko Tahun 2020. DINAMIKA KESEHATAN: JURNAL KEBIDANAN DAN KEPERAWATAN, 11(1). https://doi.org/10.33859/dksm.v11i1.609

Rodiani, R., Dananda, D. N. A., \& Berawi, K. N. (2019). Perbandingan Efektivitas Pemasangan Alat Kontrasepsi Dalam Rahim (AKDR) Pasca Persalinan dan Masa Interval. Jurnal Medula, 8(2).

Septianingrum, N. M. A. N., Fitriana Yuliastuti, \& Widarika Santi Hapsari. (2019). Pemanfaatan dan Penggunaan Secara Rasional Tanaman Obat Tradisional Sebagai Terapi Swamedikasi di Kampung KB, Magersari Kota Magelang. Engagement: Jurnal Pengabdian Kepada Masyarakat, 3(2). https://doi.org/10.29062/engagement.v3i2.33

Susanti, S., Sujianti, S., \& Pranowo, S. (2020). Peningkatan Pengetahuan Ibu Tentang Metode Kontrasepsi Jangka Panjang Sebagai Upaya Menekan Risiko Kehamilan. Jurnal Abdimas Kesehatan Tasikmalaya, 2(02). https://doi.org/10.48186/abdimas.v2i02.322

Wulandari, Y., Noer, R. M., Purwaningsih, P., Samosir, R. S., \& Panjaitan, S. T. (2020). Edukasi Program Keluarga Berencana Dan Penggunaan Alat Kontrasepsi Pada PUS (Pasangan Usia Subur) Di Rw 02 Kelurahan Tanjung Riau Batam. Community Development Journal: Jurnal Pengabdian Masyarakat, 1(2). https://doi.org/10.31004/cdj.v1i2.723 